\title{
Kronik hepatitli ve karaciğer sirozlu hastaların biyoelektrik impedans yöntemi ile değerlendirilmesi
}

\author{
Evaluation of chronic hepatitis and cirrhotic patients with bioelectrical impedance analysis
}

\author{
Haşim NAR ${ }^{1}$, Idris KIRHAN², Hüseyin TAŞKIRAN² , Çiğdem CINDOĞLU², Ahmet UYANIKOĞLU³ ${ }^{3}$ Necati YENICE ${ }^{3}$ \\ Elazığ Eğitim ve Araştırma Hastanesi, 'Gastroenteroloji Servisi, Elazığ \\ Harran Üniversitesi Tıp Fakültesi, ${ }^{2}$ ¿ç Hastalıkları Anabilim Dalı, ${ }^{3}$ Gastroenteroloji Bilim Dalı, Şanlıurfa
}

\begin{abstract}
Giriş ve Amaç: Bu çalışmada, kronik hepatitli, sirozlu ve sağlıklı bireyler arasında biyoelektriksel impedans analiz yöntemi ile fark olup olmadığının araştııılması amaçlanmıştır. Gereç ve Yöntem: Çalışmaya Haziran 2012-2013 tarihleri arasında Harran Üniversitesi Tıp Fakültesi, Gastroenteroloji polikliniğinde takip edilen 31 kronik hepatit B ve kronik hepatit C hastası, 35 karaciğer sirozu ve 38 sağlıklı erişkin alındı. Olgular kronik hepatit, karaciğer sirozu ve sağlıkı kontrol olarak üç gruba ayrıldı. Olguların yaş, cinsiyet, boy, kilo, hematokrit, sodyum, potasyum değerleri ve biyoelektriksel impedans analiz ölçümü sonrası elde edilen değerler kaydedildi ve istatistiksel analiz yapıldı. Bulgular: Siroz grubunun hematokrit ve sodyum değeri anlamlı olarak düşüktü $(p<0.05)$. Vücut kapasitans değeri kronik hepatitli grupta ve siroz grubunda kontrol grubuna göre yüksekti $(p<0.05)$. Kronik hepatitli grupta rezistans kontrol grubuna göre düşüktü ( $p<0.05)$. Vücut hücre kitlesi kronik hepatitli grupta kontrol grubuna göre yüksekti $(p<0.05)$. Kronik hepatitli grupta bazal metabolik hiz kontrol grubuna göre yüksekti $(p<0.05)$. Kronik hepatitli grubun yağsız vücut kitlesi kontrol grubuna göre yüksekti ( $p$ $<0.05$ ). Kronik hepatitli grubun intrasellüler sIVI ve total vücut suyu kontrol grubuna göre yüksekti ( $p<0.05)$. Faz açısı kronik hepatitli grupta diğer gruplara göre yüksek olsa da istatistiksel olarak anlamlı değildi ( $p$ $>0.05$ ). Sonuç: Biyoelektriksel impedans analiz ile sirotik grupta, kontrol ve kronik hepatitli grupla karşılaştırıldığında anlamlı bir değişiklik saptanmamasına rağmen kronik hepatitli grupta saptanan değişiklikler biyoelektriksel impedans analiz açııından ilerisi için ümit vericidir.
\end{abstract}

Anahtar kelimeler: Kronik hepatit, biyoelektrik impedans, karaciğer biyopsisi

\section{GíRiş}

Karaciğer sirozu (KCS), karaciğer yapısının yaygın olarak hepatosellüler nekroz, rejenerasyon, nodüler oluşum ve fibroz doku ile bozularak değişmesi sonucu meydana gelen ilerleyici bir hastalıktır $(1,2)$. Ülkemizde karaciğer sirozunun nedenleri başlıca kronik hepatit B ve $C$ olmak üzere viral hepatitlerdir (3-6).

Hepatit B virüs (HBV) enfeksiyonu dünyadaki en yaygın enfeksiyonlardan biridir. Ülkemizde ve dünyanın bazı
Background and Aims: The aim of this study was to investigate whether there was a difference between chronic hepatitis patients, cirrhotic patients, and healthy individuals with bioelectrical impedance analysis method. Materials and Methods: Between June 2012 and June 2013, 31 chronic hepatitis B and C patients, 35 cirrhotic patients who had been followed up in the Gastroenterology outpatient clinic at Harran University Faculty of Medicine and 38 healthy individuals were included in the study. Cases were divided into three groups as chronic hepatitis, liver cirrhosis, and healthy controls. Each patient's age, sex, height, weight, hematocrit, sodium, potassium values, and values obtained after bioelectrical impedance analysis measurements were recorded and a statistical analysis was performed. Results: The cirrhotic group's hematocrit and blood sodium level were significantly lower $(p<.05)$. The body capacitance value in the chronic hepatitis and cirrhosis group was higher than that in the control group $(p<.05)$. Resistance in the chronic hepatitis $B$ group was lower than that in the control group $(p<.05)$. The body cell mass value in the chronic hepatitis group was higher than that in the control group $(p<.05)$. The chronic hepatitis group's basal metabolic rate value was higher than that of the control group $(p<.05)$. The chronic hepatitis group's lean body mass value was higher than that of the control group $(p<.05)$. The chronic hepatitis group's intracellular water and total body water values were higher than both of these were in the control group $(p<.05)$. The phase angle was higher in the chronic hepatitis group when compared with other groups, but was not statistically significant $(p>.05)$. Conclusion: Although this study did not find significant changes between cirrhotic patients, chronic hepatitis patients, and control groups with bioelectrical impedance analysis, detecting any changes in patients with chronic hepatitis is promising for the future regarding bioelectrical impedance analysis.

Key words: Chronic hepatitis, bioelectrical impedance, liver biopsy

bölgelerinde de kronik hepatitlerin en önemli nedenlerindendir. Dünya Sağlık Örgütü (DSÖ) verilerine göre, tüm dünyada yaklaşık 350-400 milyon kişi bu virüsü taşımakta, her yıl 1-2 milyon kişi doğrudan HBV enfeksiyonu ve komplikasyonlarına bağlı olarak yaşamını kaybetmektedir. Hepatit C virüs (HCV) enfeksiyonu tüm dünyada yaygın ve oldukça ciddi bir sağlık sorununu oluşturur. Dünyada HCV enfeksiyonunun ortalama sıklığı \%3 olup, yaklaşık 210 milyon insan HCV ile enfektedir (7). 
Kronik HBV ve kronik HCV'de tedavi endikasyonlarının tespit edilebilmesi için doğru tanı testlerine intiyaç vardır. Tanı testleri içinde, serolojik testler, viral yükün belirlenmesi ve karaciğer biyopsisi yapılması önem taşır. Kronik viral hepatitlerin tanı ve evrelendirilmesi, karaciğer biyopsisinin başlıca endikasyonları arasında yer alır $(8,9)$.

Karaciğer biyopsisinin komplikasyonlar, örnekleme hatası ve patolog değişkenliği gibi kısıtlamaları vardır ve invaziv bir yöntemdir. Özellikle komplikasyonlar ve invaziv bir işlem olduğundan biyopsinin yerini alabilecek non-invaziv testler günümüzde önem kazanmaktadır (10-13).

Biyoelektriksel impedans analizi (BIA) vücuda elektrotlar bağlanarak uygulanan ve vücuda verilen düşük frekanslı akıma karşı oluşan direnç, faz açısı (FA) gibi değerlerin hesaplandığı ve vücut bileşenlerinin (su, kas, yağ) öngörülebildiği basit, ucuz, invaziv olmayan, taşınabilir bir yöntemdir (14).

Bu çalışmada kronik hepatitli, sirozlu ve sağlıklı bireylerin arasında BíA yöntemi ile fark olup olmadığının araştırıması amaçlanmışır.

\section{GEREÇ ve YÖNTEM}

\section{Biyoelektriksel İmpedans Analizi}

Tüm maddeler sürekli elektrik akımının (DC) akmasına karşı bir direnç $(R)$ gösterirler. Eğer bir madde üzerinden bir alternatif akım akarsa, bu madde bu akıma karşı, frekansa bağlı olarak, kompleks bir direnç oluşturur. Bu dirence de impedans denilmektedir. Impedans tanımına bağlı olarak biyolojik maddelerin alternatif akımına karşı oluşturdukları dirence de 'Biyoimpedans' denilmektedir. BIA vücut kompozisyonunu değerlendirmede kullanilır. Doku yatağına elektrotlar aracilığı ile değişik frekanslarda alternatif akımlar verilir ve akımın voltajındaki düşme 'impedans' olarak tespit edilir. Impedans dokunun elektrik akımına gösterdiği dirençtir, iletkenlikle ters orantılıdır. Elektrolitten zengin sıvılar elektrik akımı için, yağ ve kemik dokusundaki minerallere göre daha düşük direnç oluştururlar. Bu fenomen BíA kullanımının temelinde yatan prensiptir. Tüm vücut ve bölgesel impedansdaki değişkenlik doku kompozisyonu ile ilişkilidir (15). Bu nedenle doku suyu, sıvı ve ilişkili yağsız yumuşak dokuya göre ölçülen impedansı birbiriyle ilişkilendiren formüller geliştirilmiştir $(16,17)$. 50 kHz gibi yüksek akımlar hücre membranlarını geçerek tüm vücut suyunun (TVS, total body water) miktarını verirken, $1 \mathrm{kHz}$ gibi düşük akımlar hücre membranını geçemez ve sadece ekstraselLüler sıvı (ESS, extracellular water) miktarını verirler. Elde edilen impedans değerinin sabit denklemlerde yerine konması ile vücut yağ oranı (VYO), vücut yağ miktarı (VYM, fat mass), yağsız vücut yüzdesi (YVY, \% lean body mass), yağsız vücut kitlesi (YVK, lean body mass), total vücut suyu (TVS, total body water), vücut kitle indeksi (VKi) gibi vücut bileşenleri hesaplanmaktadır (15). Oda sıcaklığında, dört saat süreyle gıda ve sıvı almadan, boş mesane ile sırtüstü yatar pozisyonda ölçüm alınmalıdır (18).

\section{Hastalar ve Yöntem}

Araştırmaya Harran Üniversitesi Tıp Fakültesi, Gastroenteroloji polikliniğine başvuran ve kronik hepatit $\mathrm{B}$, kronik hepatit $C$, karaciğer sirozu tanısı almış hastalar ve 38 sağıklı erişkin alındı. Kronik B ve $C$ hepatitli toplam 31 hasta birinci grubu, karaciğer sirozlu 35 hasta ikinci grubu ve sağlıklı 38 olgu üçüncü grubu oluşturacak şekilde üç gruba ayrıldı. Vücut ağırlığı ve kompozisyonu BíA yöntemiyle saptandı. Vücut kompozisyonu ölçümleri için denekler dört saat süreyle gıda ve sıvı almadı. İslemde Biodynamics BIA 450, USA Bioimpedance Analyzer cihazı kullanıldı.

\section{Biyoelektrik İmpedans Ölçümü}

Sağ ya da sol el bileği dorsal yüze ve el bileği distalinde metakarpo-falangeal eklem hizasına elektrotlar yapıştırıdı ve aynı taraf ayak bileği ve distalinde metatarso-falangeal eklem birleşimi noktasına elektrotlar yapıştırılmak suretiyle cihaz üzerindeki panele yaş, cinsiyet, boy, kilo verileri girilerek ölçüm yapıldı. Kan hematokrit, sodyum ve potasyum değerleri ölçüldü. BíA yöntemiyle tüm deneklerin, faz açısı (FA), vücut kapasitansı (BC), rezistans $(R)$, reaktans $(R c)$, vücut hücre kitlesi $(B C M)$, ekstrasellüler kitle (ECM), yağsız vücut kitlesi (LBM), yağ kitlesi (FM), ESK/VHK, vücut kitle indeksi (BMI), bazal metabolik hız (BMR), intrasellüler sIVI (IW), ekstraselüler SIVI (EW) litre, ESS yüzde (\%), total vücut suyu (TBW), TBW/YB, TBW/ Total ağırlık değerleri ölçüldü.

\section{İstatistik}

Üç grup arasındaki karşılaştırmalar için Kruskal Wallis testi kullanıldı. Anlamlı sonuç bulunan parametrelerde iki grup karşılaştırmaları için Mann-Whitney U testi kullanıldı. Anlamlıık düzeyi için $p<0.05$ alındı. İstatistiksel analizler için SPSS (Statistical Package for Social Sciences) for Windows 18 programı kullanıldı.

\section{BULGULAR}

Kontrol grubunda ortalama yaş 40.1, ortalama boy 164.3 $\mathrm{cm}$, ortalama kilo $69.7 \mathrm{~kg}$, kronik hepatitli grupta ortalama yaş 42.7 yll, ortalama boy $167.1 \mathrm{~cm}$, ortalama kilo 75 $\mathrm{kg}$, siroz grubunda ortalama yaş $52.6 \mathrm{yll}$, ortalama boy $165.1 \mathrm{~cm}$, ortalama kilo $72.9 \mathrm{~kg}$ idi. 
Üç grup karşılaştırıldığında siroz grubunun hematokrit değeri kontrol ve kronik hepatit grubuna göre anlamlı olarak düşük ( $p<0.05)$, kronik hepatitli grubun sirozlu gruba göre kan sodyum değeri anlamlı olarak yüksek bulundu ( $p<0.05$ ). Gruplar arasında potasyum değerinde anlamlı fark bulunmadı. Demografik ve laboratuvar bulguları Tablo 1'de verilmiştir.
BİA yöntemiyle ölçülen faz açısı, vücut kapasitans, rezistans, reaktans, vücut hücre kitlesi, ekstrasellüler kitle, yağsız vücut kitlesi, yağ kitlesi, vücut kitle indeksi, bazal metabolik hız, intrasellüler sıvı, ekstrasellüler sıvı, total vücut suyu gibi parametrelerin, gruplara göre ortalama değerleri, istatistik yöntemlerle kıyaslandı. Sonuçlar Tablo 2'de gösterilmiştir.

Tablo 1. Grupların yaş, boy, kilo, hematokrit, sodyum ve potasyum ortalama değerleri

\begin{tabular}{|c|c|c|c|c|}
\hline & Kontrol & Kronik Hepatit & Siroz & p Değeri \\
\hline Yaş (yıl) & 40.1 & 42.7 & 52.6 & $p<0.05$ \\
\hline Boy $(\mathrm{cm})$ & 164.3 & 167,1 & 165,1 & $p>0.5$ \\
\hline Kilo (kg) & 69.7 & 75 & 72.9 & $p>0.5$ \\
\hline Hematokrit (\%) & 42.6 & 45.8 & 40.5 & $p<0.05$ \\
\hline Sodyum (mEq/L) & 138.1 & 139 & 137 & $p<0.05$ \\
\hline Potasyum (mEq/L) & 4.1 & 4.3 & 4.3 & $p>0.5$ \\
\hline
\end{tabular}

Tablo 2. BíA (Biyoelektriksel impedans analizi) sonuçlarının gruplara göre ortalama değerleri

\begin{tabular}{|c|c|c|c|c|}
\hline & Kontrol & Kronik Hepatit & Siroz & p Değeri \\
\hline $\mathrm{FA}\left({ }^{\circ}\right)$ & 7.06 & 8.17 & 7.67 & $p>0.5$ \\
\hline VK (pF) & 621.5 & 763.2 & 683.8 & $p<0.05$ \\
\hline $\mathrm{R}$ (ohm) & 633.5 & 572.4 & 618.9 & $p<0.05$ \\
\hline $\mathrm{Rc}(\mathrm{ohm})$ & 79.6 & 105.5 & 91.7 & $p>0.5$ \\
\hline VHK kg & 22.3 & 26.8 & 23.7 & $p<0.05$ \\
\hline VHK \% & 33.3 & 35.5 & 32.4 & $p>0.5$ \\
\hline ESK kg & 23.3 & 26.9 & 24.2 & $p>0.5$ \\
\hline ESK \% & 34 & 33.5 & 34.3 & $p>0.5$ \\
\hline YVK kg & 45.6 & 53.7 & 47.9 & $p<0.05$ \\
\hline YVK \% & 67.4 & 71.1 & 66.2 & $p>0.5$ \\
\hline YK kg & 23 & 23.3 & 25 & $p>0.5$ \\
\hline YK \% & 32.6 & 28.8 & 33.7 & $p>0.5$ \\
\hline ESK/VHK & 1.08 & 1.01 & 1.06 & $p>0.5$ \\
\hline VKi (kg/m2) & 25.5 & 27.2 & 26.6 & $p>0.5$ \\
\hline $\mathrm{BMH}$ & 1424 & 1678 & 1495 & $p<0.05$ \\
\hline iss litre & 18.9 & 23.1 & 20.6 & $p<0.05$ \\
\hline iss \% & 56.9 & 59.1 & 58.7 & $p>0.5$ \\
\hline ESS litre & 14.4 & 16.1 & 14.6 & \\
\hline ESS \% & 43 & 40.8 & 41.2 & \\
\hline TVS litre & 33.4 & 39.2 & 36.7 & $p<0.05$ \\
\hline TVS/YVK & 90.4 & 71.5 & 73.5 & $p>0.5$ \\
\hline TVS/Total ağırlık & 49.6 & 52.5 & 48.8 & $p>0.5$ \\
\hline
\end{tabular}

FA: Faz açısı, VK: Vücut kapasitans, R: Rezistans, Rc: Reaktans, VHK: Vücut hücre kitlesi, ESK: Ekstrasellüler kitle, YVK: Yağsız vücut kitlesi, YK: Yağ kitlesi, VKI: Vücut kitle indeksi, BMH: Bazal metabolik hız, iss: Intrasellüler sıvı, ESS: Ekstrasellüler sıvı, TVS: Total vücut suyu. 


\section{TARTIŞMA}

Karaciğer biyopsisi kronik hepatitlerde önceki dönemlerde yalnız tanı amacıyla uygulanırken, günümüzde tedaviye cevabın değerlendirilmesi ve takip amacıyla da yaygın olarak yapılmaktadır. Hastaların klinik bulguları ve karaciğer fonksiyon testleri ile histopatolojik bulgular genellikle korelasyon göstermektedir. Kronik viral hepatitlerin tanı ve evrelendirilmesi karaciğer biyopsisinin başlıca endikasyonları arasında yer alır (8). Bu çalışma kronik hepatitlerdeki dinamik inflamatuvar süreç ve karaciğer sirozunda meydana gelen yapısal ve vücut kompozisyonundaki değişiklikler nedeniyle BIA yöntemi ile kronik hepatit, karaciğer sirozu ve kontrol grupları arasında saptanabilecek fark ile karaciğer biyopsisine alternatif olabileceği düşüncesiyle yapıldı.

Karaciğer sirozunda gelişen portal hipertansiyon nedeniyle plazma hacim artışı, sirozun geç evrelerinde sabit bir bulgudur (19). Bu nedenle bizde BİA ölçümleri sonucu saptanacak vücut su dağılımının buna uygun olmasını beklerken üç grup arasında ekstrasellüler sıvı dağılımında litre ve yüzde olarak fark saptanmadı. Kronik hepatitli grubun total vücut suyunun kontrol grubuna göre anlamIı olarak yüksek olduğu saptandı. Asiti olan sirozlu hastalarda karın içi asit miktarının ölçülmesi ve değişimlerinin takibinde BIA yönteminin kullanılması önerilmemektedir $(20,21)$. Bizim çalışmamızda hastalar asit varlığı veya yokluğu ile ilgili gruplandırımamıştır ve sirotik gruptaki olguların bir kısmının asitli olduğu düşünülürse sirotik gruptaki sıvı dağııım oranlarının diğer gruplardan farklı olmaması buna bağlanabilir.

Sirotik hastaların \% 75'inde anemi görülür. Bu zaman zaman kanama ve hemolize bağlı olabileceği gibi kronik hastalık anemisi de görülebilir. Serum elektrolit değişiklikleri özellikle hiponatremi karşımıza çıkar (22). Bizim çalışmamızda da buna uyumlu olarak sirotik grupta kan hematokrit değerleri kontrol ve kronik hepatit grubuna göre anlamlı olarak düşüktü. Kronik hepatitli gruba göre de siroz grubunun kan sodyum değeri anlamlı olarak düşüktü.

Çalışmamızda BIA yöntemi ile ölçülen ortalama bazal metabolik hız kronik hepatitli grupta kontrol grubuna göre anlamlı olarak yüksekti. Yine bu grupta yağsız vücut kitlesi ve vücut hücre kitlesi kontrol grubuna göre anlamlı

\section{KAYNAKLAR}

1. Harrison's Principles of Internal Medicine 16th Edition 2005;1858-9.

2. Memik F, Dolar E. Karaciğer sirozu. Tabak F, editör. Klinik Gastroenteroloji. I. Baskı, İstanbul; Nobel ve Güneş Tıp Kitapevleri. 2005;626-33. olarak yüksek, rezistans değeri ise kontrol grubuna göre anlamlı olarak düşüktü. Ayrıca kronik hepatitli grupta intrasellüler sıvı ve total vücut sıvısının da kontrol grubuna göre yüksek olması yukarıdaki bulguları desteklemekteydi. Vücut hücre kitlesindeki artış ile beraber total vücut kapasitansı da kontrol grubuna göre artmıştı.

BIA ölçümü ile elde edilen rezistans ve kapasitans değerlerinden hesaplanan faz açısı (FA) insan vücudundaki sıvı (rezistans) ve hücresel membranların (kapasitans) göreceli oranlarını yansıtır. Faz açısı kapasitans ile doğru, rezistans ile ters orantılıdır. Faz açısı intra ve ekstrasellüler sıvı dağılımı hakkında fikir verir ve bu da malnütrisyonun en önemli indikatörlerinden biridir. BIA ile elde edilen faz açısı hücresel membran bütünlüğünün bozulduğu ve sıvı dağılımında değişiklikler olan malnütrisyon, ileri neoplastik hastalıklar ve karaciğer sirozu gibi klinik durumlarda prognostik bilgi verebilir (23). Guida ve arkadaşları yüksek faz açısı ile yüksek VKi arasındaki korelasyona dikkat çekmişlerdir (24). Yaşla birlikte faz açısının azaldığı tespit edilirken Barbosa-Silva ve arkadaşları bu ilişkide olası olarak yağ dokusunun rezistansının etkili olduğunu bildirmişlerdir (25). Selberg ve arkadaşları karaciğer sirozlu hastalarda 5.4 derece ve daha düşük faz açısının kısa sağ kalım süresi ile ilişkili olduğunu göstermişlerdir (26). Sirozlu hastalarda beslenme durumunu ölçmede yatak başı metotlar arasında BiA kullanarak vücut hücre kitlesi (BCM) veya faz açısı saptamanın, antropometrik yöntemlere göre daha üstün olduğu düşünülmektedir (27). Ancak bizim çalışmamızda beklenenin aksine siroz grubunda diğer gruplarla karşılaştııılığında faz açısı yönünden anlamlı fark yoktu. VKi yönünden de gruplar arası fark saptanmadı. Siroz grubunda vücut hücre kitlesinde de yine kontrol gruba göre fark saptanmazken kronik hepatitli grupta kontrole göre vücut hücre kitlesi anlamlı olarak yüksekti.

Sonuç olarak bizim çalışmamızda BíA ile sirotik grupla kronik hepatit ve kontrol grupları karşılaştıııldığında anlamlı bir değişiklik saptanmamasına rağmen kronik hepatitli grupta saptanan bazal metabolik hız, yağsız vücut kitlesi, vücut hücre kitlesi, intrasellüler sıvı ve total vücut sıvısındaki istatistiksel anlamlı yükseklik ve istatistiksel olarak anlamlı olmasa da faz açısındaki yükselme ve bu bulgulara uyumlu olarak rezistans değerindeki anlamlı düşüklük ileriki çalısmalar için umut vericidir. Bu konuda daha fazla çalışma yapılmasına intiyaç vardır.

3. Tabak F, Yurdaydın C, Kaymakoğlu S, et al; Guidelines Study Group $\mathrm{VH}$. Diagnosis, management and treatment of hepatitis B virus infection: Turkey 2017 Clinical Practice Guidelines. Turk J Gastroenterol 2017;28(Suppl 2):73-83. 
4. Idilman R, Baykam N, Kaymakoğlu S, et al; Guidelines Study Group VH. Turkey 2017 Clinical Practice Guidelines on recommendations for screening diagnosing and managing hepatitis C virus. Turk J Gastroenterol 2017 Dec;28(Suppl 2):90-93.

5. Ökten A, Mungan Z, Çakaloğlu Y. Karaciğer sirozu: Gastroenterohepatoloji. Nobel Tıp Kitapevi 2001;449-50.

6. Ökten A. Türkiye'de karaciğer sirozunun etiyolojisi. Hepatolojide Güncel Gelişmeler Sempozyumu Kitabı,1998; 67.

7. Quer J, Esteban J. Epidemiology. In: Thomas HC, Lemon S, Zuck erman AJ (eds). Viral hepatitis. Massachusetts, USA. Third Edition. Blackwell Publishing, 2005;407-25.

8. Bravo AA, Sheth SG, Chopra S. Liver biopsy. N Engl J Med 2001;344:495-500.

9. Şahin $M$, Karayakar F, Erdogan KE, et al. Liver tissue trace element levels in HepB patients and the relationship of these elements with histological injury in the liver and with clinical parameters. J Trace Elem Med Biol 2018;45:70-77.

10. Dienstag JL. The role of liver biopsy in chronic hepatitis C. Hepatology 2002;36(5 Suppl 1):S152-60.

11. Bedossa P, Poynard T. An algorithm fort he grading of activity in chronic hepatitis C. The METAVIR Cooperative Study Group. Hepatology 1996;24:289-93.

12. Silva $A M$, Matias $C N$, Nunes $C L$, et al. Lack of agreement of in vivo raw bioimpedance measurements obtained from two single and multi-frequency bioelectrical impedance devices. Eur J Clin Nutr 2018 Oct 22. [Epub ahead of print]

13. Ruiz-Vargas A, Ivorra A, Arkwright JW. Design, Construction and Validation of an Electrical Impedance Probe with Contact Force and Temperature Sensors Suitable for in-vivo Measurements. Sci Rep 2018;8:14818.

14. Kushner RF. Bioelectrical impedance analysis: a review of principles and applications. J Am Coll Nutr 1992;11:199-209.

15. Baumgartner RN, Chumlea WC, Roche AF. Impedance for body composition. Exerc Sport Sci Rev 1990;18:193-224.

16. Houtkopper LB, Lohman TG, Going SB, Howell WH. Why bioelectrical impedance analysis should be used for estimating adiposity. Am J Clin Nutr 1996;64(3 Suppl):436S-448S.
17. Köksal I, Yılmaz G, Parlak M, et al; Study Group TCHC. Diagnostic value of combined serum biomarkers for the evaluation of liver fibrosis in chronic hepatitis $C$ infection: A multicenter, non interventional, observational study. Turk J Gastroenterol 2018;29:464-472.

18. Kushner RF, Guidivaka R, Scholler DA. Clinical characteristics influencig bioelectrical impedance analysis measurements. Am J Clin Nutr 1996;64(3 Suppl):423S-427S.

19. Kravetz D, Arderiu MT, Bosch J, et al. Increased plasma volume in two models of portal hypertension in the rat: Cirrhosis of the liver and partial portal vein ligation. Rev Esp Fisiol 1987;43:179-83.

20. Guglielmi FW, Contento F, Laddaga L, et al. Bioelectric impedance analysis: experience with male patients with cirrhosis. Hepatology 1991;13:892-5.

21. Cabré E, de León R, Planas R, et al. Reliability of bioelectric impedance analysis as a method of nutritional monitoring in cirrhosis with ascites. Gastroenterol Hepatol 1995;18:359-65.

22. Runyon BA, Montano AA, Akriviadis EA, et al. The serum ascites albumin gradient is superior to the exudates-transudate concept in the differential diagnosis of ascites. Ann Int Med 1992;117:215-20.

23. Kahraman A, Hilsenbeck J, Nyga $M$, et al. Bioelectrical impedance analysis in clinical practice: implications for hepatitis $C$ therapy BIA and hepatitis C. Virol J 2010;7:191.

24. Guida B, Laccetti R, Gerardi C, et al. Bioelectrical impedance analysis and agerelated differences of body composition in the elderly. Nutr Metab Cardiovasc Dis 2007;17:175-80.

25. Barbosa-Silva MC, Barros AJ, Wang J, et al. Bioelectrical impedance analysis: population reference values for phase angle by age and sex. Am J Clin Nutr 2005;82:49-52.

26. Selberg O, Selberg D. Norms and correlates of bioimpedance phase angle in healthy human subjects, hospitalized patients, and patients with liver cirrhosis. Eur J Appl Physiol 2002;86:509-16.

27. Pirlich M, Schutz T, Spachos T, et al. Bioelectrical impedance analysis is a useful bedside technique to assess malnutrition in cirrhotic patients with and without ascites. Hepatology 2000;32:1208-15. 